\title{
O FIM D’ARTISTA:
DESCONSTRUÇÃO E RECONSTRUÇÃO DO EU
PELO PROCESSO CRIATIVO
}

\section{O FIM D`ARTISTA: DECONSTRUCTION AND RECONSTRUCTION OF THE SELF BY CREATIVE PROCESS \\ Jéssica Becker ${ }^{1}$}




\section{Resumo}

Análise do como a interiorização do Outro e exteriorização de si pode gerar controvérsias entre identidade social e identidade pessoal de cada indivíduo, a partir das teorias identitárias do filósofo francês Clement Rosset. Levantamento da posição da mulher enquanto artista e mãe e, logo, da realidade vivida no paralelo entre o fazer artístico e a vivência da maternidade. Investigação da desconstrução e reconstrução do Eu através do processo criativo. Metodologia teórico-prática, que culmina na produção e exame do vídeo O Fim d'artista, em 2016, tendo como principais referenciais práticos as proposições artísticas e autobiográficas de Louise Bourgeois, Mônica Mayers e Esther Ferrer, especialmente. Este artigo é parte da pesquisa de doutorado (2017. PPGAV-UFRGS).

Palavras-chave: identidade, o Eu, O Outro, mulher, maternidade.

\section{Abstract}

Analysis of how internalization of the other and exteriorization of itself can generate controversies between social identity and personal identity of each individual, taken from the theories of identity of French Philosopher Clement Rosset. Survey about women position as an artist and mother and, then, the lived reality in parallel between the creative act and motherhood.The study of deconstruction and reconstruction of the Self through the creative process. Theoretical practical methodology, that culminates with a production and analysis of the video O Fim d'artista, in 2016, taking as main practical references the artistic and autobiographic propositions from Louise Bourgeois, Mônica Mayers and Esther Ferrer, mainly. Thisarticleispartof a doctoralresearch. (2017. PPGAV-UFRGS).

Keywords: Identity, the Self, the Other, women, motherhood.

ISSN: 2175-2346

1 jessicaaraujobecker@hotmail.com 


\section{Introdução}

O encontro com o Outro pode ser um propulsor na construção do Eu-artista e de suas narrativas. Nesta hipótese, pode a prática artística ser um meio de acolhimento deste Outro externo? Existe uma interiorização do Outro na identidade individual do artista, que se reflete em suas proposições? Como pode o artista ainda reconhecer-se em sua individualidade?

Destes questionamentos é que o presente artigo levanta suas reflexões, retomando parte da pesquisa de doutorado (2017, PPGAV-UFRGS) ${ }^{1}$ para melhor desenvolver a problemática da construção da identidade individual e do processo artístico a partir do contato com o Outro. A tese referida foi desenvolvida sobre dois momentos de seu período investigativo-prático: o primeiro em que o trânsito e o desarraigo motivavam a prática de ações, performances e intervenções em âmbito externo e estrangeiro; e o segundo dado a partir do retorno à cidade natal, tendo o arraigo como motivo da elaboração e prática de vídeos. Tal dado é significativo para a compreensão do presente texto uma vez que este disserta, justamente, sobre esta segunda parte da investigação doutoral, onde a perspectiva intimista e autobiográfica se sobressai.

Possuindo como principal aporte teórico os estudos sobre identidade do filósofo francês Clement Rosset, o presente artigo está dividido em três seções (além da Introdução e das Considerações Finais): Contextualização do problema e debate sobre a posição da mulher e da maternidade em relação ao próprio processo criativo e identitário, recorrendo como referenciais práticos às artistas Marina Abramovic, Louise Bourgeois e Monica Mayers; O autobiográfico e o vídeo no processo de percepção identitária, construindo analogias com a obra Femme Maison de Louise Bourgeois, com o texto $O$ Narrador de Walter Benjamin e com os vídeos de mulheres-artistas da década de 1970, especialmente, Martha Rosler e Ulrick Rosenbach; A desconstrução do Eu pela prática do vídeo $O$ fim d' artista (2016), em afinidade com trabalhos específicos de Esther Ferrer, Fernanda Bec e Micheline Torres.

Desta forma, busca-se dar a ver, através da reflexão teórica e do levantamento de uma prática, possibilidades de desconstrução e reconstrução da identidade de um artista, isso em sua relação com o Outro e em seu processo criativo.

\section{Identidade-mãe: a mulher e a maternidade no processo criativo}

A prática acional em contextos estrangeiros, o trânsito além fronteiras e o trabalho com temáticas relacionadas à identidade, foram as constantes do processo criativo que desenvolvi desde o ano de 2006 a 2013. A evolução das investigações deste período deu origem à pesquisa de doutorado e às proposições da primeira parte desta. No entanto, as contingências do devir, a partir de 2014, especialmente a

\footnotetext{
1 O Eu e o Outro: Alteridade e Identidade na Construção do Processo Criativo. PPGAV-IA/UFRGS, 2017. Pesquisa teórico-prática, ancorada no desenvolvimento de proposições artísticas em vídeo e arte de ação, em contexto estrangeiro e local, público e privado. Com metodologia que articulava tais proposições sob a reflexão e a análise comparativa com referenciais práticos e investigação bibliográfica, os conceitos norteadores que envolveram as questões apresentadas se encontravam em interdisciplinaridade entre problemáticas próprias da arte e outros campos de estudos, como as ciências sociais, a filosofia e a psicanálise.

2 As práticas desenvolvidas na primeira parte da tese se deram na cidade de Bogotá, Colômbia, durante a Bolsa de Residências Artísticas LOCAL, oferecida pela Universidad Nacional de Colombia. Além disto, a grande maioria das práticas anteriores à tese ocorreu também em contextos internacionais, durante períodos de bolsas de estudo que obtive na Argentina e na Espanha.
} 
maternidade, me levaram ao retorno e fixação em meu local de origem, propiciando o resgate de minhas raízes e o fortalecimento destas na interação com o contexto. $A$ qualidade de ser mãe me fez reconstruir hábitos e me reconhecer em uma identidade diferente: pesquisadora-mãe-artista, propiciando o contato com um Outro próximo, familiar e íntimo.

A artista Marina Abramovic, em entrevista ao jornal virtual Málaga Hoy, quando questionada sobre a visão da mulher artista, da maternidade e da interpretação desta sobre o mundo contemporâneo, afirma:

Las mujeres no están tan preparadas para sacrificarse por el arte como los hombres. Las mujeres quieren tener familia e hijos y además dedicarse al arte. Pero, siento decirlo, eso no es posible. Tenemos um cuerpo y para ser artista hay que consagrarlo a ello por completo. El arte exige el sacrificio de todo, incluída la vida normal. (ABRAMOVIC, 2014) ${ }^{3}$.

O posicionamento de Abramovic, a meu ver, é equivocado ao reduzir a mulher a uma mera e iludida sonhadora de lares quando, ao contrário, estas se sacrificam para desempenhar tantos papéis na vida, seja artista, mãe, dona de casa, empresária, pesquisadora, etc. O lugar da mulher na sociedade, desde a década de 1970, especialmente, vem sendo debatido e exigido não somente por causas feministas, mas está implícito ao dia a dia de cada uma de nós. A arte tem sido espaço para a manifestação da mulher sobre seu cotidiano, seus problemas, sua crítica social. Abramovic, ao afirmar que consagra seu corpo à arte, posição visível nesta artista que leva às suas performances toda sua energia vital, mostra o quão sagrado sua obra significa diante de sua existência, porém, sua postura é romântica frente ao ato criativo. Supervalorizando a criação sobre quaisquer outros aspectos do cotidiano e isolando o artista de uma vida dita "normal", a artista parece, pois, ver como incompatível a dedicação compartilhada entre obra e filhos.

Concordo que a investigação e escrita de uma tese, a produção artística e a maternidade nem sempre se encontram de mãos dadas. Mudanças significativas ocorrem quando do surgimento de um novo "cosmos" que é a chegada de um filho na vida de uma mulher. Contudo, surpreende-me que Abramovic afirme que as mulheres não estão dispostas a sacrificar-se pela arte como estão os homens, visto que a arte da mãe-artista se nutre e caminha junto a tantos acontecimentos paralelos. Também, a artista minimiza e reduz a importância de outras grandes mulheres que dedicaram sua vida no paralelo entre arte-filhos, como é o caso de Louise Bourgeois.

A importância que Louise Bourgeois possui no campo das mulheres-artistas é dada não somente por seu papel precursor na arte feminista dos anos 1970, em Nova York, e da identidade autobiográfica apresentada por suas obras, mas também por ser uma das primeiras a levantar o tema da maternidade nestas. Sua história pessoal, amplamente conhecida pela relação que possuía com o pai, a mãe e os irmãos, nem sempre perpassa por sua condição de mãe e por seus filhos, porém, também esta é intrínseca e fundamental para a apreensão de suas proposições.

3 Entrevista realizada por Pablo Bujalance Málaga, no dia 24 de maio de 2014, previamente à abertura da exposição Holding emptiness, retrospectiva sobre Marina Abramovic no Centro de Arte Contemporânea de Málaga. Disponível em: http://www.granadahoy.com/ocio/dejar-muerte-buena-basura-material_0_810219419. html. Acessado em: 29 mar 2018. 
Bourgeois teve três filhos homens. O primeiro, Michel, adotado na França em um momento em que a artista, por questões burocráticas e políticas, teve que decidir-se entre permanecer nos Estados Unidos, onde fora naturalizada e possuía já uma carreira como artista, ou voltar e novamente fixava-se em seu país natal, para só então poder realizar a adoção (BERNARDAC; BOURGEOIS; OBRIST, 2000, p.160). Aos 28 anos e vivendo os anos 1940, a artista conta, na obra citada, o sentimento de estar no entremeio de seus direitos de ser mãe ou ser artista. Escolha esta que, felizmente, não ocorreu, visto que Bourgeois conquistou e realizou ambas. Mais tarde, teve naturalmente outros dois filhos homens, que the suscitaram a curiosa sensação andrógina, também vista em suas obras, pelo fato de possuir, dentro de si, um outro corpo de sexo oposto.

A história de vida de seus filhos não é de conhecimento público, visto que, entre outras coisas, as obras de Bourgeois não tratam deles, mas sim da mãe. A representação da maternidade, em geral, e pelo que descreveu Bourgeois, a remete diversas vezes a sua mãe, porém estimo que a visão de docilidade, passividade e amor que a artista tem sobre esta provêm e é altamente influenciada pelo que ela própria aprendeu sendo mãe. Vale o dito que "só compreendemos nossos pais, verdadeiramente, depois que nos tornamos pais".

Mesmo possuindo uma percepção dotada de meiguice e ternura sobre sua mãe, a maternidade apresentada nas obras de Bourgeois é posicionada e feminista. Talvez por não concordar com a posição passiva da mãe diante das traições e desígnios do pai, a artista constrói trabalhos onde a mulher deve ser forte, ativa e empoderada. Vejo isto, por exemplo, na figura recorrente e emblemática em sua obra que é a grande aranha (Figura 1).

Várias vezes relacionada à sua mãe, como uma homenagem, a aranha gigantesca de Bourgeois é feita em metal pesado, o que a faz aparentar ainda mais uma força grotesca e amedrontadora, visto que é a representação de um animal peçonhento. No entanto, na experiência pessoal que tive com esta obra em São Paulo, ao posicionar-me embaixo de suas pernas, o que é possível dado suas dimensões, esta me transmitiu uma curiosa e inquietante sensação de proteção. Na ambivalência medo-aconchego, sua forma é como um abrigo e, ao vê-la de baixo para cima, com sua bolsa (de tela metálica) cheia de ovos (bolas de mármore), parecia-me terna. Uma mãe que carrega seus filhos dentro de si ou, por vezes, já nascidos, sobre seu ventre, e que constrói, sozinha, seu lar, com a teia que é parte de seu corpo. 


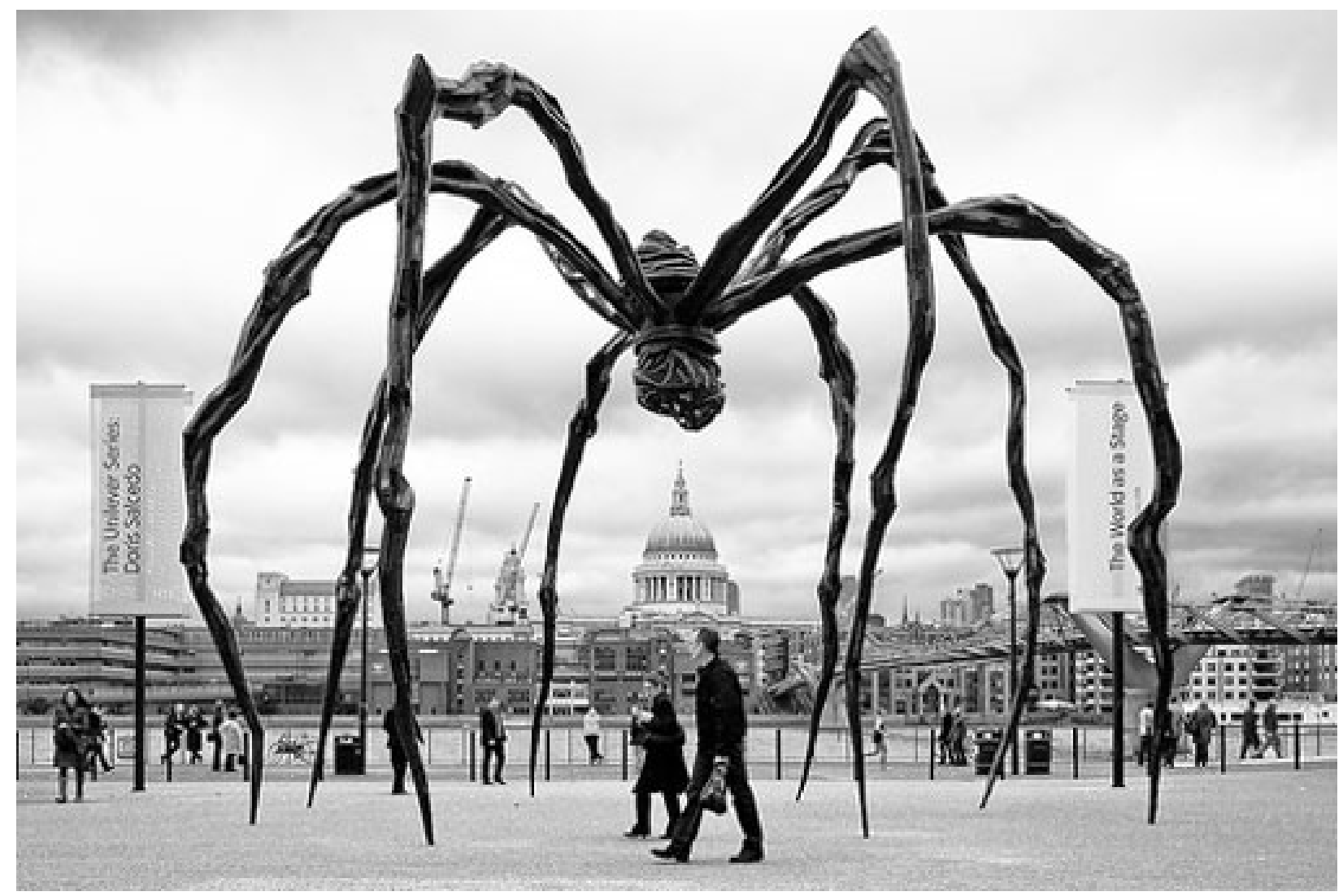

Fig. 1 - LOUISE BOURGEOIS, Maman,1999, Londres/Inglaterra.

Fonte: https://echostains.files.wordpress.com/2012/09/bourgeois-spider.jpg

A maternidade em Bourgeois é expressa pela contradição entre uma imagem que remete à violência e um significado profundo de afetividade e carinho. Com uma aranha ou, muitas vezes, apresentando o corpo feminino sem cabeça - símbolos e homenagens à mãe, esta é reconstruída em grandes dimensões ou em pequenos fragmentos, como de fato a maternidade se apresenta em nossas vidas.

Outra referência na conciliação entre arte e maternidade é encontrada em determinados trabalhos da artista mexicana Mônica Mayers. Atuante na performance desde os anos 1980, Mayers é defensora e adicta à arte feminista, constantemente tratando de temas de violência e desigualdade de gênero, bem como de outras questões envoltas na situação da mulher contemporânea.

Em seu livro Rosa Chillante: mujeres y performance en México ${ }^{4}$, Mônica Mayers, mais do que apenas dissertar sobre o histórico da performance feminina, realiza uma narração desde sua própria experiência. Participando dos primeiros movimentos feministas na arte mexicana, especialmente com ações individuais e coletivas, Mayers é ativista desta causa, realizando proposições que envolvem o público no mundo da mulher.

Em 1983, Mayers e Maris Bustamante, também performer, se reuniram para criar o primeiro coletivo feminista do México. Sendo tomado como algo radical para a época, o grupo chamado Polvo de Gallina Negra (que é um "pó-mágico" para "mau-olhado" no México) tinha como objetivos:

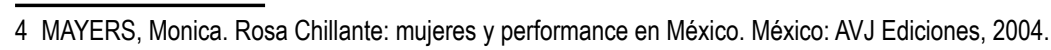


- Analisar a imagem da mulher na arte e nos meios de comunicação

- Estudar e promover a participação da mulher na arte

- Criar proposições a partir da experiência de ser mulher em um sistema patriarcal, baseadas em uma perspectiva feminista e objetivando transformar o mundo visual e assim alterar a realidade (MAYERS, 2004, p.38).

Assim, o coletivo PGN (Polvo de Gallina Negra) realizou diversas performances ao longo de dez anos de trabalho, tendo como projeto mais ambicioso o chamado ¡Madres!. Interessadas na temática da maternidade, as duas participantes do grupo, como primeiro passo e para sucesso do projeto, decidiram engravidar em datas próximas, vivenciando o que isso implicaria como ação artística. Em seu livro, Mônica relata que ambas, "como boas feministas" (MAYERS, 2004, p.39), engravidaram de meninas, Yuruen e Andrea, que nasceram com 3 meses de diferença no ano de 1985. A partir daí, realizaram performances ao vivo, arte postal, conferências, ações participativas, e determinaram que seu coletivo seria um grupo endógamo, isto é, somente os descendentes co-sanguíneos das três artistas poderiam integrar-se a ele.

Das proposições criadas pelo grupo, instiga-me a chamada Carta a mi madre. Nesta, em uma convocatória pública, convidavam os possíveis colaboradores a escreverem uma carta a sua mãe dizendo-lhe algo que nunca antes haviam se atrevido. Receberam 70 cartas de todo país com relatos, narrações e poemas sobre a maternidade, finalizando a convocatória com um evento de premiação à melhor carta enviada, analisada e julgada pelas artistas.

Direcionando o olhar à relação mãe e filho, Carta a mi madre oportuniza o partícipe a extrair, através de palavras, todos os seus pensamentos, desejos, inconformismos em relação à figura mitificada da mãe. Oportunizar ao Outro a chance de examinar sua história pessoal com a própria mãe é também um meio de análise da condição feminina, mesmo que, muitas vezes, a mãe não seja percebida como mulher. O trabalho de Mayer faz-nos observar a conexão filho-mãe pela exterioridade da intimidade do ser, levantando questões como: o que dizer à própria mãe tardiamente? Por que razões não ter falado antes? Que tipos de vínculos existem nesta ligação? O que é ser filho e o que é ser mãe? O que existe de dependência, submissão e silêncio, em ambos os lados, nesta relação?

Outro trabalho do grupo PNG que aqui faço alusão é a ação realizada durante uma entrevista para a qual as artistas foram convidadas, em um programa reconhecido de televisão mexicano (Nuestro Mundo), chamada Madre por um día (1987) (Figura 2)5. Apontando para a desigualdade entre o papel do homem e da mulher frente a uma gravidez, Mônica e Maris observaram que, em sua sociedade, determinados homens deveriam, de alguma forma e por algum momento, experimentar a oportunidade de ser mãe por um dia, sendo um destes, justamente, o apresentador do programa, Guillermo Ochoa. Neste fim, levaram à entrevista barrigas falsas de gravidez coladas sob aventais de cozinha, induzindo o apresentador a vesti-las; também colocaram neste uma coroa de "rainha do lar", lhe ofereceram pílulas para os "males" comuns da gravidez, como: desejos, medo, enjôo, ansiedade, e lhe presentearam com um "Diário do primeiro homem grávido", com dicas, sugestões, opiniões, conselhos e superstições a serem seguidas durante a gravidez.

5 MAYERS, Monica; BUSTAMANTE, Maris. Madre por um día. Ciudad de México: 1987. Nuestro Mundo. Entrevista concedida a Guillermo Ochoa. Disponível em: https://www.youtube.com/watch?v=abaDXr3HKck. Acesso em: 29 mar. 2018 


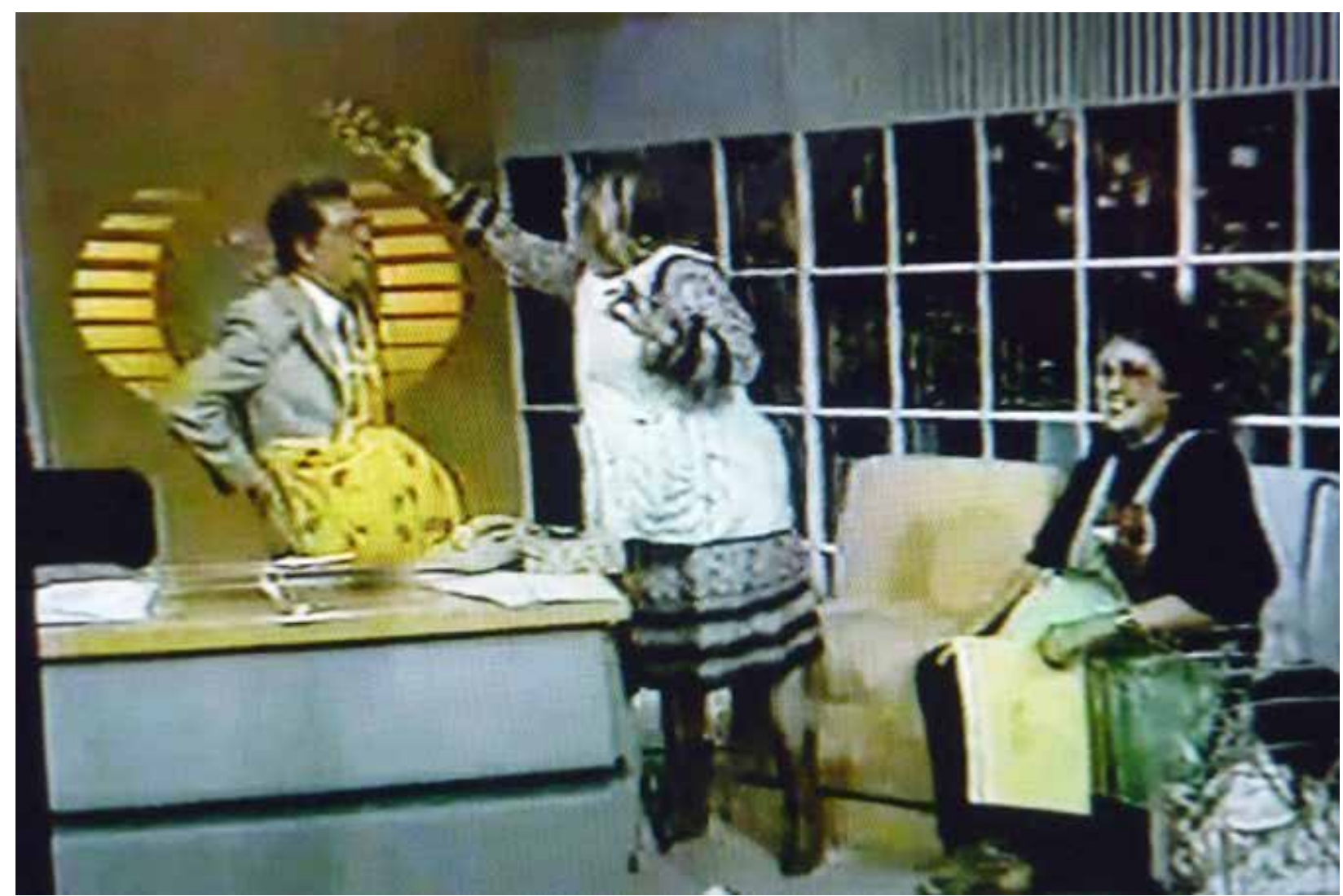

Fig. 2 - MÔNICA MAYERS E MARIS BUSTAMANTE, Madre por um día, Ciudad de México/México, 1987. Fonte: MAYERS, 2004.

A ideia estereotipada e popular da mulher e de sua gravidez era nesta ação levantada e criticada pela ênfase de atos recorrentes deste período. Longe do desejo de incitar o riso na exposição das desconjunturas da gravidez, está o posicionamento feminista e condenatório sobre os pressupostos que a sociedade, patriarcal e machista, impõe sobre a mulher nesta fase de sua vida. O fato de fazer com que um homem, de reconhecimento nacional, leve uma barriga, um avental e uma coroa de rainha do lar, talvez não faça com que este entenda, sinta ou assimile o que é estar "grávido", mas sobretudo, discute e põe em cheque a imagem masculina presente nos meios de comunicação.

Por sua vez, o apresentador Ochoa participou da ação "vestindo a personagem", ironizando atitudes comuns às grávidas, como a dificuldade de sentar-se, a vontade de comer determinados alimentos, a felicidade quando o bebê se mexe. Mantendo a ideologia do sistema machista das telecomunicações, mesmo diante de ações de cunho crítico a esta, Ochoa satirizou, a modo "populacho", a figura feminina da grávida, o que, contudo, não pormenorizou a crítica incisiva que a ação ali colocava.

A sociedade em que vivemos constrói, alimenta e impõe uma figura irreal e ilusória à figura materna. Achando graça da mulher sob um avental, da coroa que a qualifica como grande rainha do lar e da barriga que carrega durante o período de gravidez, como vimos no trabalho do PNG, nutre-se um modelo destituído de originalidade e identidade. Posicionando a mulher na cozinha, no lar, frente ao tanque, ao varal, como mãe, dona de casa, doméstica, constrói-se a imagem fantasiosa, e nada conveniente de sua existência. A mulher atual, mesmo que hoje já ativa e determinada de convicções antimachistas, ainda sofre a pressão social-dominante do machismo. 


\section{Identidade em crise e o vídeo autobiográfico}

Durante os primeiros meses de vida de um filho, muitas são as mudanças, não somente físicas e hormonais, na mulher-mãe, mas também em suas posições de pensamento, opinião e ação.

Havendo toda uma necessidade de dedicação ao filho, especialmente em seus primeiros meses, eu, como mulher, me engrandeci como mãe, tirando forças de onde nem poderia saber, mas também me fragmentei, diminui e me perdi em pedaços pequenos, sendo diferente do que era antes. A confusão sobre os papéis de minha existência deu-se logo dos primeiros dias de nascimento de minha filha, perdurando por alguns meses, até a assimilação da nova condição que se me apresentava.

Havendo pouco ou nada do que antes entendia como Eu, assimilava tal situação com a filosofia identitária de Clement Rosset quando este afirma:

[...] cada vez que se produz uma crise de identidade, a identidade social é o primeiro que se estilhaça, ameaçando o frágil edifício do que cremos experimentar como Eu; é sempre uma deficiência da identidade social o que vem a perturbar a identidade pessoal e não ao contrário, como se tende a pensar geralmente. (ROSSET, 2007, p.18).

O que parecia fugir e distanciar-se de mim mesma era, sobretudo, o Eu social que até então havia construído. Uma identidade que alimentava a personagem de mulher independente, ambiciosa em seus planos e corajosa em suas realizações. Com anos de estudo, dedicara boa parte de meu tempo a este, na expectativa de um futuro maior e de sucesso. Sendo reconhecida em meus esforços, viajara sozinha a lugares não comuns ao meio familiar ou de amizades que convivo. Adquiri conhecimentos, experiência, autonomia e domínio sobre esta existência. A aparência que transmitia, a meu ver, era de segurança e sucesso frente aos meus pares, com uma carreira promissora e opiniões firmes e decididas. Previa um caminho lógico e prudente a seguir, com metas definidas, objetivos prescritos e alvo na mira.

Mas o período de arraigo ao qual me dedicara, mais do que necessidade, fora uma estratégia, inconsciente, de segurança e conforto frente à nova realidade que se me impunha. Minhas ideias e planos passaram à observação deste complexo mundo íntimo. Em oposição à condição desarraigada que construíra na primeira etapa da tese, viajando para outras cidades, regiões, países, onde o alcance dos meus olhos não possuía dimensão, agora me arraigava a pouco mais de $100 \mathrm{~m} 2$, bem menos, eu diria, à distância entre dois olhares: o meu e de minha menina.

Seja a rua ou o lar, o espaço experimentado é sempre um lugar de subjetivação (principalmente para o artista), que promove e constrói, junto à alteridade, sujeitos. Louise Bourgeois, em 1945, Nova York, constrói uma série de trabalhos intitulada Femme Maison (Figura 3), que mostra corpos femininos cuja cabeça possui o formato de uma casa. A mulher como cabeça da casa e a casa como cabeça da mulher resgatam a ideia de dominação popular do patriarcado que destina, designa e nomeia, à mulher, o lar como seu lugar. Os cuidados com a casa, com os filhos, com o jardim, com a comida, os afazeres domésticos seguem, ainda hoje, mas não em todos os lares e felizmente cada vez menos, como imperativos à mulher. Em geral, hoje é ela quem 
rege a casa, governa, designa e distribui tarefas, mesmo que, também, esta função de "poder" mascare, ainda e muitas vezes, um posicionamento despótico, objetivo ou subjetivo do homem sobre a mulher.
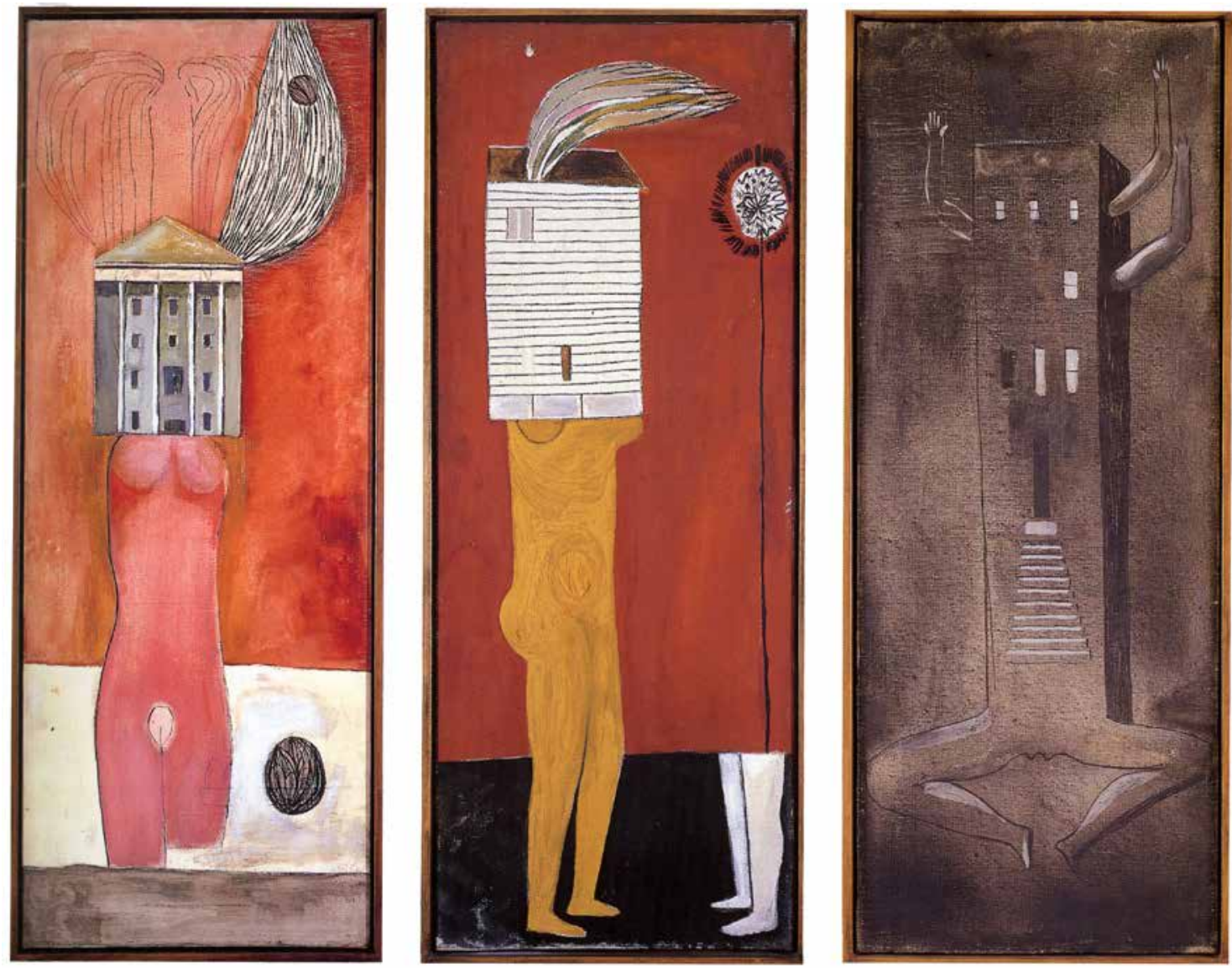

Fig. 3 - LOUISE BOURGEOIS, Femme Maison, Nova York, 1945. Fonte: BERNARC, 2000.

O sentimento de clausura e privação dado pela existência privada à casa, junto ao esvaziamento de si mesmo, ambos envoltos nos tantos afazeres da maternidade, fazia-me buscar, na visão do Outro, um reflexo de mim em parte dele. Novamente amparada por Clement Rosset, este afirma:

[...] começo a inquietar-me por mim mesmo, ou pelo $\mathrm{O} E u$, não quando deixo de me reconhecer (quem poderia por outro lado reconhecer-se), mas sim, ao contrário, quando são os outros quem deixam de me reconhecer, [...] que dizem estar vendo, com seus próprios olhos, e que eu sou incapaz de observar [...]. (ROSSET, 2007, p.18).

Para ROSSET, é na percepção do Outro, por aquele que nos olha, que se dá nossa própria existência. O reconhecimento que este emprega sobre a individualidade que a cada um pertence, é o que nos coloca no mundo enquanto ser, visto que somos incapazes de perceber "nosso próprio sabor".

De fato, a identidade que antes o Outro percebia em mim havia, pois, se estilhaçado, e sua falta esvaziava-me. Contudo, passei a observar que existiam na minha pessoa novos elementos que podiam me dar significado, e que eram referências para este Outro (minha filha) que havia gerado. Uma inversão de papeis, onde de receptora do que 
me era externo e alheio, passara a emissora, propulsora, produtora. Uma identidade pessoal, diferente, surgia e, aparentemente único e indivisível, este Eu se refletia, mais que isso, era mote, no processo artístico e nas proposições que estavam sendo criadas.

Ainda que toda arte seja expressão de ideias e opiniões, as proposições autobiográficas detêm, justamente, seu fazer e sua teoria, sobre o pensar em si mesmo, construindo-se a partir de um Eu próprio, particular e único, que é o artista em seu mundo.

Em proposições geradas a partir de experiências pessoais e, por isso, singulares, o artista que escolhe o caminho do autobiográfico marca, por assim dizer, a alteridade enquanto diferença e enquanto semelhança frente ao Outro. Isto porque o trabalho autobiográfico, além de expor particularidades, dá a ver uma percepção do cotidiano legítima e verdadeira, buscando a aproximação com o público pela identificação e assimilação destas particularidades. Pela singularidade alcança-se o comum, o corriqueiro e o fugaz, mostrando formas de vida a serem apreendidas em sua condição de proximidade ou distância do Outro espectador.

Ao voltar-me para o entorno e às situações que o devir até aqui me trouxera, observei que nos trabalhos que daí surgiam existia, pois, a necessidade de construção ou reafirmação de uma identidade autora, querendo dar a ver ao Outro sua existência. Assim, o autobiográfico se constrói posicionando o artista não somente como autor-produtor, mas como um autor-sujeito das proposições que narra por meio da linguagem artística, dos fatos, das situações e das circunstâncias particulares, mas comuns e assimiláveis por todos.

Se este artista é um contador de suas próprias experiências, pode-se construir uma relação com o que Walter Benjamin afirmou em seu texto O Narrador, de $1936^{6}$. Afirmando a narração em sua condição de permanência temporal, muito à frente de um relatório ou apenas da transmissão de uma informação passageira e fugaz presente em sua época e também na atual, esta conta, constrói e reconstrói fatos e feitos de um ser real, por este ou por outro, na oralidade, na escrita ou por outra linguagem, como em meu caso. Sobre esta narrativa, Benjamin coloca:

Ela mergulha a coisa na vida do narrador para em seguida retirá-la dele. Assim, se imprime na narrativa a marca do narrador, como a mão do oleiro na argila do vaso. [...] Seu dom é poder contar sua vida, sua dignidade é contá-la inteira. (BENJAMIN, 1996, p.205-221).

A matéria do narrador e, em meu entendimento, do artista que recorre ao autobiográfico é, pois, a vida humana, e não qualquer uma, mas a sua própria. Mergulhar em sua existência para, como afirma Benjamin, depois retirá-la de si mesmo, faz com que este artista se debruce sobre uma análise de autoconhecimento que terá como fim a construção de um autor, que cria a partir de si, mas em direção ao Outro. 0 olhar para si próprio, pra seu entorno e para a contingência de circunstâncias próximas, para destes extrair uma visão consideravelmente apreensível pelo Outro, requer um Eu-narrador conhecido e sabido de si próprio, um sujeito.

\footnotetext{
6 Ciente de que o texto de Benjamin refere-se a um espaço-tempo diferente e transformado socialmente em relação ao atual, considero aqui o conceito maior de narrador por ele sugerido, ligado, especialmente, à necessidade de intercâmbio de experiências e também da pobreza de experiências comunicáveis, onde a narração é um modo de construção de relações entre indivíduos, história e tempo.
} 
Os meios que irão ser utilizados para expor a biografia deste narrador da própria vida são inúmeros, e ao longo da história tem encontrado abrigo nas diferentes linguagens do campo sensível da arte.

O vídeo sempre me foi um companheiro. Seja como meio de registro de ações, como produção própria da linguagem artística do vídeo ou em videoinstalações ${ }^{7}, 0$ interesse por este, culminado por minha dissertação de Máster em Producción Artística ${ }^{8}$, chega à minha tese como linguagem ideal ao momento presente. Encontrando-me arraigada, e sabendo que, pela observação do privado, instâncias autorreferenciais seriam o aspecto central dos trabalhos, encontrei no vídeo o meio de expor estas contingências.

As artes visuais, em geral, são artes solitárias comparativamente a outras expressões como o teatro, a música ou a dança. Dentro dessas, o vídeo surge nos anos 1960, se estende pelo campo nos anos 1970 e 1980, e evolui, enquanto linguagem, posteriormente. Tendo sua maior particularidade ligada à construção de imagens em movimento, o vídeo utiliza uma tecnologia democrática, de grande potencial criativo, acessível economicamente (cada vez mais), de fácil conduta e manejo e que não necessita de grandes espaços físicos nem para sua produção, nem para sua distribuição e exibição.

Exigindo apenas uma câmera, seja fotográfica ou mesmo em um celular, e um computador com softwares de edição de imagens em movimento e, talvez, internet, o vídeo me possibilitou, na situação de arraigo em que me encontrava, a criação artística pela palavra, pelo som, e também, claro, pela imagem sequencializada. Escolhendo o vídeo como linguagem, principalmente, pela possibilidade de agrupamento em um só trabalho destes três elementos citados (imagem, áudio e movimento), pela primeira vez decidi pela ausência de minha pessoa enquanto personagem-imagem realizadora de ações. $O$ desaparecimento desta figura representava a ênfase numa identidade em crise da artista, porém, também direcionava a atenção mais ao conteúdo do que ao contentor, ao íntimo do que ao público, ao Eu do que ao Outro.

A exibição e difusão do que é particular de um indivíduo através de uma sequência de imagens ou palavras, dando movimento a estas, fazia-me pensar o vídeo como um meio capaz de incorporar as contingências do dia a dia. Um diário eletrônico, onde as anotações, como uma narrativa, não propriamente relatavam uma intimidade, mas a mostravam em ações, palavras e imagens compiladas.

Esta apropriação da característica intimista do vídeo, seu uso como um modo de captação do real diário, ou como um espelho, em que o artista se coloca somente junto à câmera ou ao computador, sem a intervenção e/ou interação com outras pessoas, foi amplamente empregada por diversos artistas na década de 1970. Rosalind Krauss, em artigo de 1976, afirmou ser o vídeo uma arte essencialmente narcisista, na qual a figura do artista, sua imagem, semblante e corpo, eram o meio de expressão,

\footnotetext{
7 Agrupamentos/categorizações de minha parte associadas e baseados nas contribuições de Santos Zunzunegui, que fala sobre quatro categorizações: registro de ações, que documentam performances, happenings, intervenções onde o artista se coloca frente à câmera e desenvolve uma ação, citando como exemplo os vídeos de Vito Acconci; investigações de espaço-tempo, onde a imagem-movimento é centro das questões, mostrando o transcorrer do tempo e o espaço específico criado pelo vídeo através da sequência de imagens, citando os trabalhos de Bill Viola; videoinstalações, que têm, sobretudo, a relação entre o vídeo e o espaço expositivo como cerne; e vídeo experimental, se referindo às experimentações com os aparelhos videográficos em si, com uso de sintetizadores ou com feedback ao vivo, citando o trabalho Interface, de Peter Campus (ZUNZUNEGUI, 2007).
}

8 Máster en Producción Artística. Universidad Politécnica de Valencia/Espanha, 2010. 
realizado em ações, frente a uma câmera. Também nesta década, tirando proveito da acessibilidade do aparato videográfico e da relação de intimidade que este proporcionava, pode-se ver uma ascensão de mulheres artistas, utilizando o vídeo como ferramenta de contestação, crítica e exposição das suas condições frente à sociedade da época. Dando a ver o posicionamento feminista dos anos 1970, artistas produziam vídeos de mulheres sobre mulheres, podendo expressar-se por este meio de grande e fácil difusão e apreensão geral. A professora e teórica de vídeo-arte espanhola Lorena Mattalía, refere-se a estas mulheres artistas e a seus trabalhos desta forma:

Muitas obras videográficas de mulheres giraram em torno ao tema da identidade, do corpo, da violência de gênero, desde o ponto de vista do feminismo, estando suas críticas mais diretamente dirigidas à imagem estereotipada da mulher imposta pela cultura oficial, à imagem como forma de violência sobre o corpo e à identidade. (MATTALÍA, 2008, p.65).

Este posicionamento e utilização do meio videográfico, como uma ferramenta de emancipação da mulher dos anos 70 , que mostra uma visão em primeira pessoa da realidade diária de cada uma, pode ser visto em diversos trabalhos: Martha Rosler, em Semiotic of the kitchen, 1975 (Figura 4), onde se vê a figura da artista em uma cozinha, parodiando os programas de culinária da época, mostrando objetos comumente relativos a esta, como um batedor de ovos, uma tigela, uma faca, e lhes dá usos estranhos e inusitados; Dara Birnbaum na série Technology Transformation: Wonder Woman, de 1978, onde a artista compila imagens da série de TV Wonder Woman, exibida nos Estados Unidos, alterando a sequencialidade com repetições que ridicularizam a personagem; Max Almy, nos vídeos Perfect Leader e The Thinker, 1989, onde se vê homens ensinando como ser um líder e como ser um ser pensante; Ulrick Rosenbach em Sorry Mister, de 1974 (Figura 5), onde a artista estapeia suas pernas, repetindo a frase autopunitiva "desculpe senhor", até que surjam grandes hematomas; Ana Mendieta, citando entre eles Blood Sign n\#2, de 1974, onde, com as mãos cortadas e ensanguentadas, as esfrega em uma parede, nua e em posição de quem "se rende" à polícia ou a outro; e na grande maioria das performances e vídeos de Marina Abramovich, como Art must be Beautiful, artist must be Beautiful, de 1975, onde se penteia repetindo a frase título: "a arte deve ser bonita, o artista deve ser bonito", aumentando a velocidade e agressividade do ato; Rest Energy, 1980, onde segura uma flecha apontada e engatilhada a ela por seu companheiro Ulay; e a série Rithm, de 1975, realizada em cinco performances e vídeos-performance, sendo a mais conhecida a que se coloca em um museu, com 72 peças sobre uma mesa, algumas perigosas como um revólver, faca e machado, deixando com que o público aplicasse sobre ela estes itens como bem desejasse. 

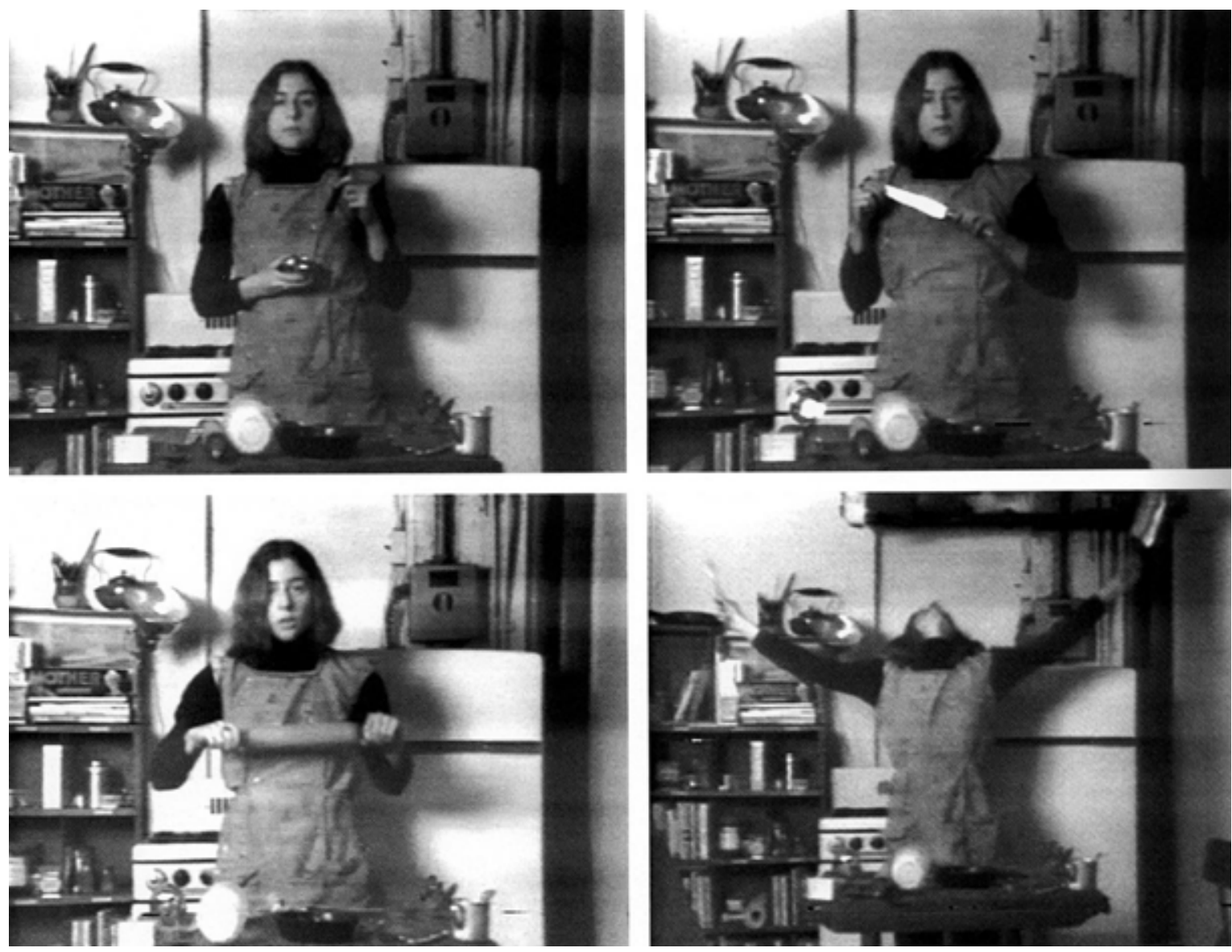

Fig. 4 - MARTHA ROSLER, Semiotic of the kitchen, 1975.

Fonte: https://www.youtube.com/watch?v=Vm5vZaE8Ysc\&t=154s
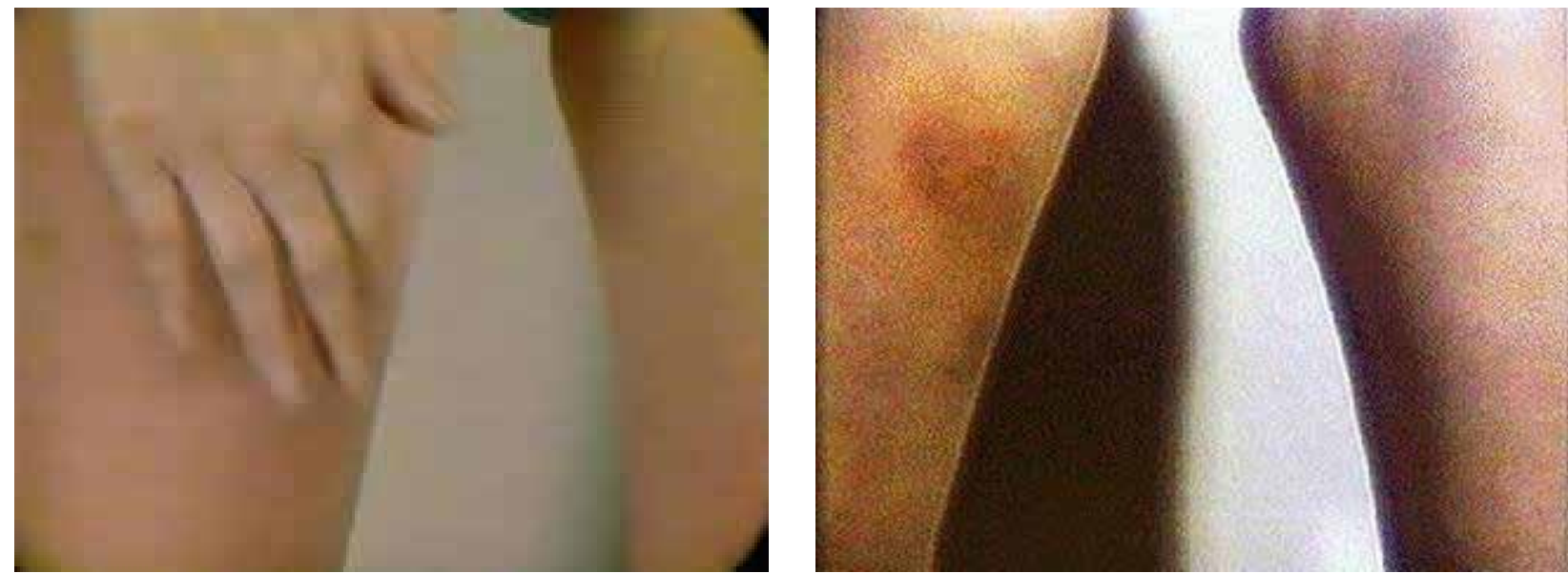

Fig. 5 - ULRICK ROSENBACH, Sorry Mister, 1974.

Fonte: https://www.youtube.com/watch?v=UWFcsDcS34U

Nestes referenciais, a presença da artista, seja direta, pela exibição de sua imagem, ou indiretamente, no trabalho de montagem de imagens compiladas, sons ou palavras, se faz como um autor-narrador que, mais do que contar, mostra sua vida, intimidade e ideias. O autobiográfico é o centro das questões destes vídeos, que exibem identidades afetadas pelas ideologias de uma época, no caso os anos 1970, mas não "rendidas" a elas. A crise identitária está presente, mas sendo confrontada através da resistência aos padrões exteriores impostos. 


\section{Desconstrução e Reconstrução do Eu}

Questionando minha própria identidade, onde estaria o que até então entendia como Eu e para onde iria esta nova existência que parecia surgir-me, desenvolvo o vídeo O fim d' artista (Figura 6) ${ }^{9}$. Recebendo este título pela relação entre objetos-documentos e configuração do ser, entre a vida que se tem antes e após a maternidade, e entre a persistência, ou não, da figura do artista diante do novo momento que se instaura em minha existência , o vídeo é um registro autobiográfico do momento em que vivia.

Ligada a ideia de acabar com os problemas por meio da trituração destes, ação já antes realizada em algumas de minhas intervenções e performances, decido triturar, em uma máquina manual de fragmentação de papéis, os documentos, títulos, certificados, registros, que me atestam como sendo quem era até tornar-me mãe, nesta ordem:

- Certidão de nascimento, 1982;

- Certificado de conclusão de curso escolar de Ensino Fundamental, em 1997;

- Carteira de identidade, produzida também em 1997;

- Certificado de conclusão de curso de Ensino Médio, em 2001;

- Título eleitoral atual, produzido em 2014;

- Título de Bacharel em Artes Visuais, 2007;

- Certificado de intercâmbio, realizado em Córdoba/Argentina, 2006;

- Diploma de Espanhol como Língua Estrangeira (D.E.L.E.), obtido em 2007;

- Láurea acadêmica, 2007;

- Título de Mestre em Artes Visuais, obtido em 2011;

- Contrato de União Estável, 2009;

- Certificado de Bolsa de Estudos pela Fundação Carolina/Espanha, 2009;

- Título de Máster Universitário em Producción Artística, 2010.

Após triturar uma a uma as cópias idênticas e fiéis destes documentos, o vídeo finaliza com a apresentação de um último certificado: o registro de nascimento de minha filha, conferindo-me um novo e inalterável título, o de mãe.

Os títulos e documentos, dentre todos e tantos outros elementos encontrados na casa, pareciam de forma mais segura e reconhecida atestar um Eu construído em instâncias formadoras e institucionais diversas. Contudo, pergunto: os documentos, registros, títulos que possuímos, são o que nos definem? Somos o que estes atestam ou estamos para além disto? A trajetória de uma vida pode ser resumida em folhas de papel, facilmente trituráveis?

Clément Rosset trata, justamente, deste duo entre possuir uma identidade social, dada pela visão do Outro e formada por um conjunto de personalidades, sentimentos, aspectos que adquirimos ao longo da vida com o contato e atestada também por documentos; e uma identidade pessoal, qualificada como íntima, própria e autêntica e que nos diferencia das demais pessoas. Nesta problemática, afirma:

[...] meu nome não é meu verdadeiro nome, nem minha idade é minha verdadeira idade. Sinalizo esta curiosa fratura que nos converte em dois seres: o ser oficial dos papéis e o ser real, mas misterioso, que nenhum documento dá conta e que de fato nenhuma aparência sinaliza. [...] A esta identidade pessoal, considerada primeira e anterior com respeito a qualquer identidade social, também se poderia

9 Este trabalho pode ser acessado em https://www.youtube.com/watch?v=J-a9GP_3Z9A\&t=1s 
chamar identidade pré-identitária, se entendemos por identitário o que certifica a documentação que um dispõe, assim como o testemunho de quem lhe rodeia. $\mathrm{O}$ eu pré-identitário se apresenta assim como o verdadeiro e autêntico eu; e o eu identitário (social) como um eu convencional que não é mais que o pano que cobre e esconde por sua vez o primeiro, e não tem mais consistência que a do papel e do rumor. (ROSSET, 2007,p. 10-12).
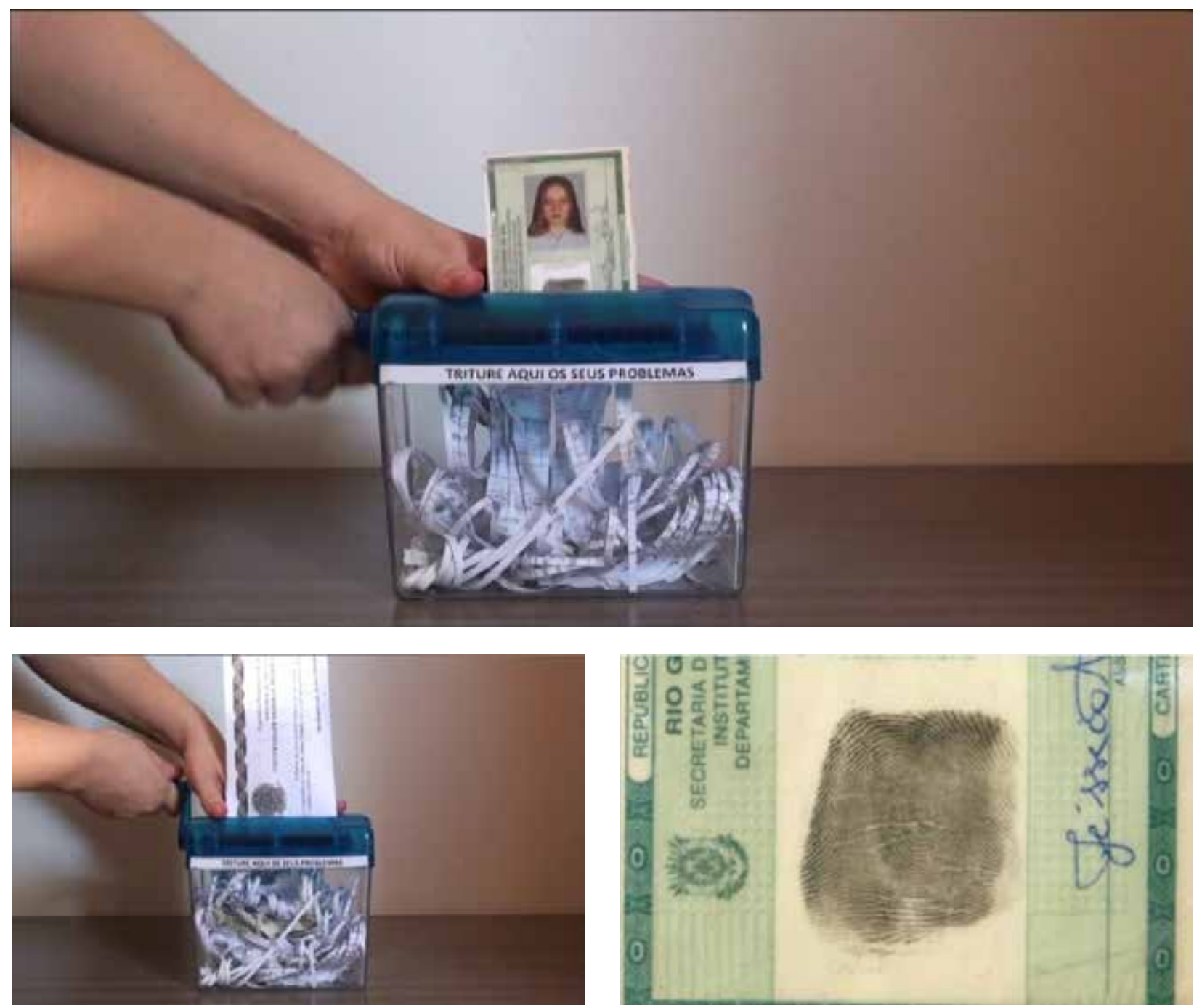

Fig. 6 - O Fim d'artista, 5'20", 2016.

Todo documento, enquanto uma afirmação escrita de caráter comprobatório, possui validez pública e atestam momentos e etapas da existência de um indivíduo. Conhece-se um pouco de alguém a partir de seus "papéis" que, tendo propriedade semântica, possibilitam a construção de uma trajetória dada.

Os documentos que trituro no vídeo são reconhecidos e valorizados pela maioria das pessoas, pois atestam uma existência. Nisto, reside uma fragilidade: se a identidade de uma pessoa é dada apenas pelos acordos sociais que firmou ao longo dos anos em papéis, se todo seu crédito está conferido a estas folhas, o que passará se estas forem destruídas, trituradas? O que é um ser sem registro de nascimento, sem carteira de identidade, títulos e diplomas? O que levaria sua destruição e o que isto significa? Por que decidi por manter apenas um único registro, no caso, a certidão de nascimento de minha filha, quando, justamente, este documento me nomina, mas não me pertence? 
É possivel conhecer parte do que sou, ou fui, através destes certificados - uma história de escolhas na qual, no entanto, tudo o que existe de pré-identitário, pessoal, verdadeiro e autêntico Eu, está apenas refletido. Esta documentação testemunha e atesta minhas decisões, escolhidas ou não, ao longo da vida, mostrando, pois, em um papel, convenções, pactos e ajustes que revelam uma identidade social construída para o Outro. Somos feitos também destes papéis que nos dão a existência frente ao Outro. Segundo Rosset, "[...] o âmbito dos feitos e gestos, como o dos papéis e documentos, ligado à identidade social, é o único que tem curso oficial; todo o demais, pertence à ordem incerta de nossas fantasias e sonhos [...]" (2007, p.23-24). O filósofo, pois, desqualifica a identidade pessoal, ou pré-identitária, remetendo o sentimento de autonomia e autenticidade do Eu ao campo do ilusório. Rosset defende que a identidade social nos constrói como um quebra-cabeças, feito de peças adquiridas pela alteridade, e de personagens a serem atuados conforme as circunstâncias. Sendo uma soma de partes de Outros, somos percebidos também, e somente, por estes. Assim, a perda de identidade seria a perda da percepção do Outro sobre aspectos previamente construídos e atestados.

Concordando com Rosset, a trituração dos documentos que testemunham minha trajetória, a decisão de manter o registro que me qualifica como mãe, e a definição do título do vídeo como $O$ fim $d^{\prime}$ artista, pretendem, sobretudo, explicitar um momento de perda de identidade dado quando de minha inserção à maternidade. Vendo-me em uma situação onde muitos limites, físicos e psicológicos, são apresentados, com as atividades reduzidas e restringidas ao tempo das necessidades do bebê, observei-me, por alguns meses, distante do que antes eu fora, sem autonomia de trânsito e de decisões, que eram agora guiadas para o pequeno ser que me definira como mãe. Longe daqueles que me observavam e me viam como artista, perguntei onde em mim esta figura se mantinha, e se o seu sacrifício (como sugere Abramovic, que decidiu pela arte) seria necessário para assumir a nova função por mim escolhida e desejada.

A identidade social que construíra havia se desmantelado, e tudo o que antes havia experimentado como Eu se colocara em dúvida. No entanto, minha identidade pessoal não era outra, mesmo que meu ser social o fosse, isto é, todas as fórmulas e comportamentos repetitivos e somáticos que antes realizava e que me qualificavam diante do Outro (como sugere Rosset), deram lugar a outros feitos e gestos que necessitavam de repetição para instaurarem-se como um novo Eu.

A trituração dos documentos e a manutenção da certidão de identidade de minha filha, apresentadas no vídeo, sugerem esta sensação, provisória, do fim de uma identidade construída a favor de outra. Trata-se, então, não de uma transição identitária vivenciada como perda, mas da percepção e aceitação do devir da existência, segundo o qual fatos importantes acarretam em grandes mudanças, exibidas pelo olhar extremo e exagerado da arte.

Sob esta perspectiva, vejo encontro da presente proposta com a ação Enterro da Performance a várias velocidades, de Esther Ferrer, realizada em 2009. Nesta, a artista, vendo-se em seus 70 anos de idade e percebendo que já quase não possuía condições de correr a várias velocidades, como o fez na versão original da performance, em 1987 (Figura 7), realizada nas ruas de Paris, resolve, pois, realizar o enterro desta. Convida 
então interessados a assistir pela última vez a performance em que corre a várias velocidades, e percorre, nessa nova ação, o breve percurso da entrada ao jazigo em que será enterrada a performance, no cemitério de Morille, Salamanca/Espanha (Figura 8). A partir daí, após breve pausa de descanso, realiza o enterro de uma caixa vermelha com alguns objetos utilizados na performance ao longo de suas outras apresentações (como um sapato), ao som da marcha fúnebre e acrescentando, ainda, uma lápide com os seguintes dizeres: "Aqui jaz a Performance a várias velocidades. Paris, 1987 - Salamanca, 2009. Inventada, realizada e transformada em múltiplas ocasiões por Esther Ferrer até 01 de agosto de 2009 em que se a realizou, pela última vez, neste cemitério.".

Ferrer, nesta performance, explicita sua conformidade com as mudanças e as alterações que a vida nos traz. Ciente e diante de sua "nova" condição, que se apresenta como natural, que é o envelhecer, decide pôr fim a um estado identitário que, anteriormente, existira e que correra a várias velocidades, diversas vezes, ao longo dos anos ${ }^{10}$.

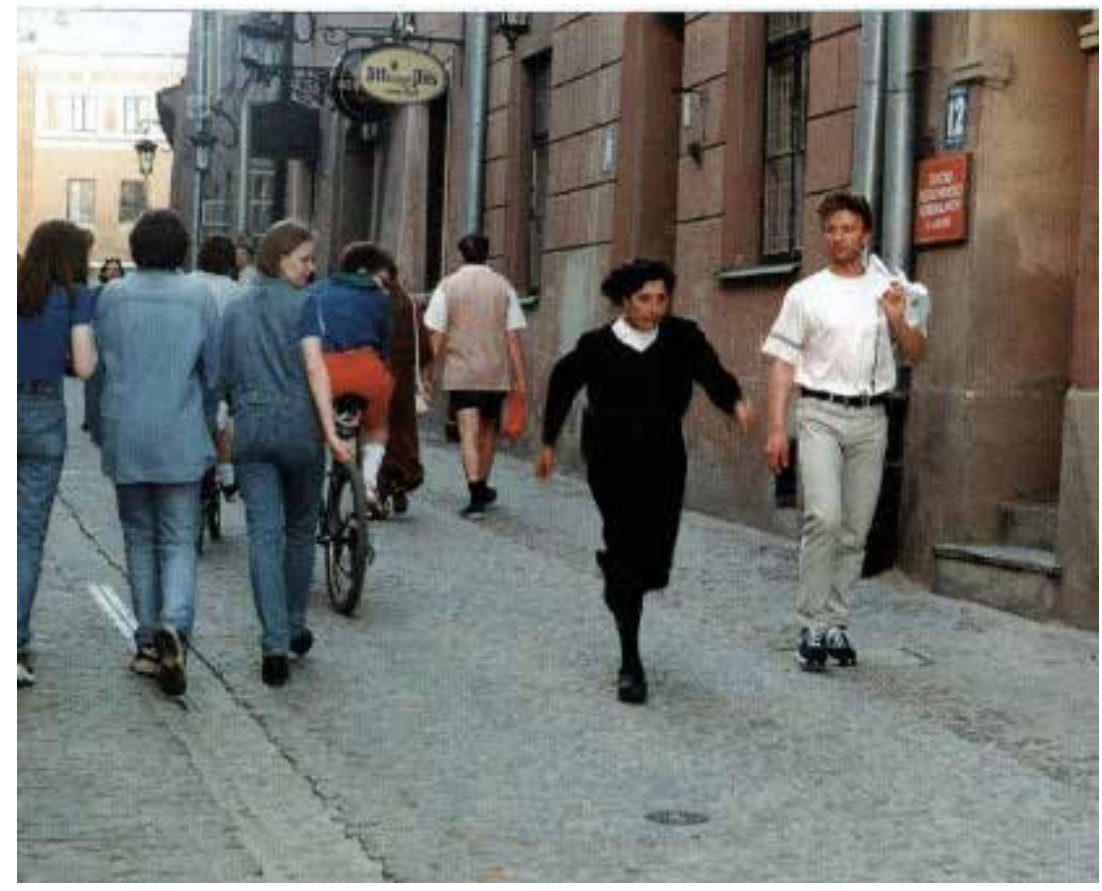

Fig. 7 - ESTHER FERRER, Corrida a várias velocidades, Paris, 1987. Fonte: http://estherferrer.fr/fr/

10 Esther Ferrer é uma artista espanhola reconhecida por suas performances em âmbito público e, nem sempre, institucionalizadas. Sendo uma artista conceitual de ampla produção desde os anos 1970 até a atualidade, não somente na arte de ação, produz também fotografias, instalações, desenhos e maquetes, todos interligados, como ela própria afirma (FERRER, 2011). É importante referência para minha prática e estudos no campo da performance desde o Máster. Nesta ocasião, tive oportunidade de conhecê-la pessoalmente, através de uma amiga em comum, visitando uma exposição sua na cidade de Valência (na qual pude registrar os trabalhos vistos na imagem 9) e acompanhando uma aula aberta em que relatou sua trajetória e posicionamentos frente à arte de ação. 

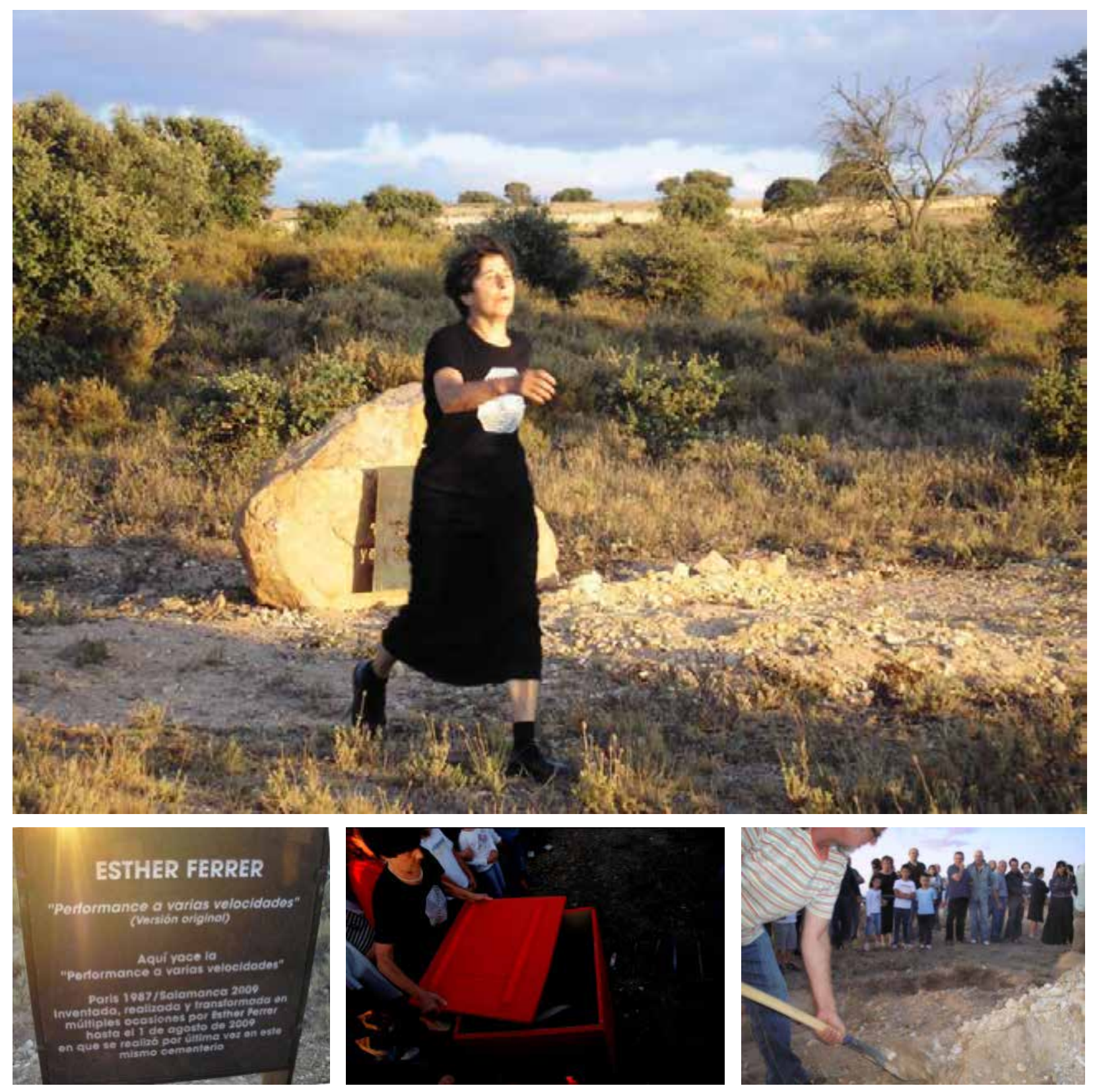

Fig. 08 - ESTHER FERRER, Enterro da Corrida a várias velocidades, Salamanca, 2009. Fonte: http://estherferrer.fr/fr/

A desconstrução do Eu, refletido e representado por diferentes elementos, ações e instâncias que colocam as questões identitárias como cerne de sua problemática, está presente em inúmeras proposições de arte feminista das últimas quatro ou cinco décadas.

Esther Ferrer é referência deste tema, desmontando-se, remontando-se, rabiscando-se, apagando-se em diversos de seus trabalhos em fotografia e performance, como na série Íntimo e Pessoal, 1977-2009 (Figura 9). Nesta, a artista apresenta fotografias de seu rosto e corpo que sofrem alterações por meio de desenhos, anotações, rabiscos e colagens sobre sua superfície. Algumas mostrando o corpo dividido em fragmentos, tem-se a figura da mulher acentuada em seus aspectos físicos próprios, expondo-se em paralelo às anotações sobre as imagens que, por vezes, referem-se aos padrões de beleza e simetria. 
Questionada em entrevista sobre a "relação de trabalho" que possui com o próprio corpo, Esther responde:

Nosotros empezamos pensando que nuestro cuerpo nos pertenece y nos ha hecho reflexionar mucho a las mujeres. Parece evidente, pero les falta a las generaciones actuales. Tienen la ilusión de que todo está conseguido, cuando está en peligro todo. Las luchas de años 60 están en peligro: el aborto, el derecho de huelga, la contracepción, muchos derechos están en la cuerda floja en Europa. En Paris vamos a las manifestaciones y estamos todas las viejas. En otro día en la del aborto por vez primera acudieron muchas chicas jóvenes y también chicos. Nuestra generación tardó en ponerse en marcha pero nos tendrán que matar para que nos echemos atrás. (FERRER, 2014. p.:2)
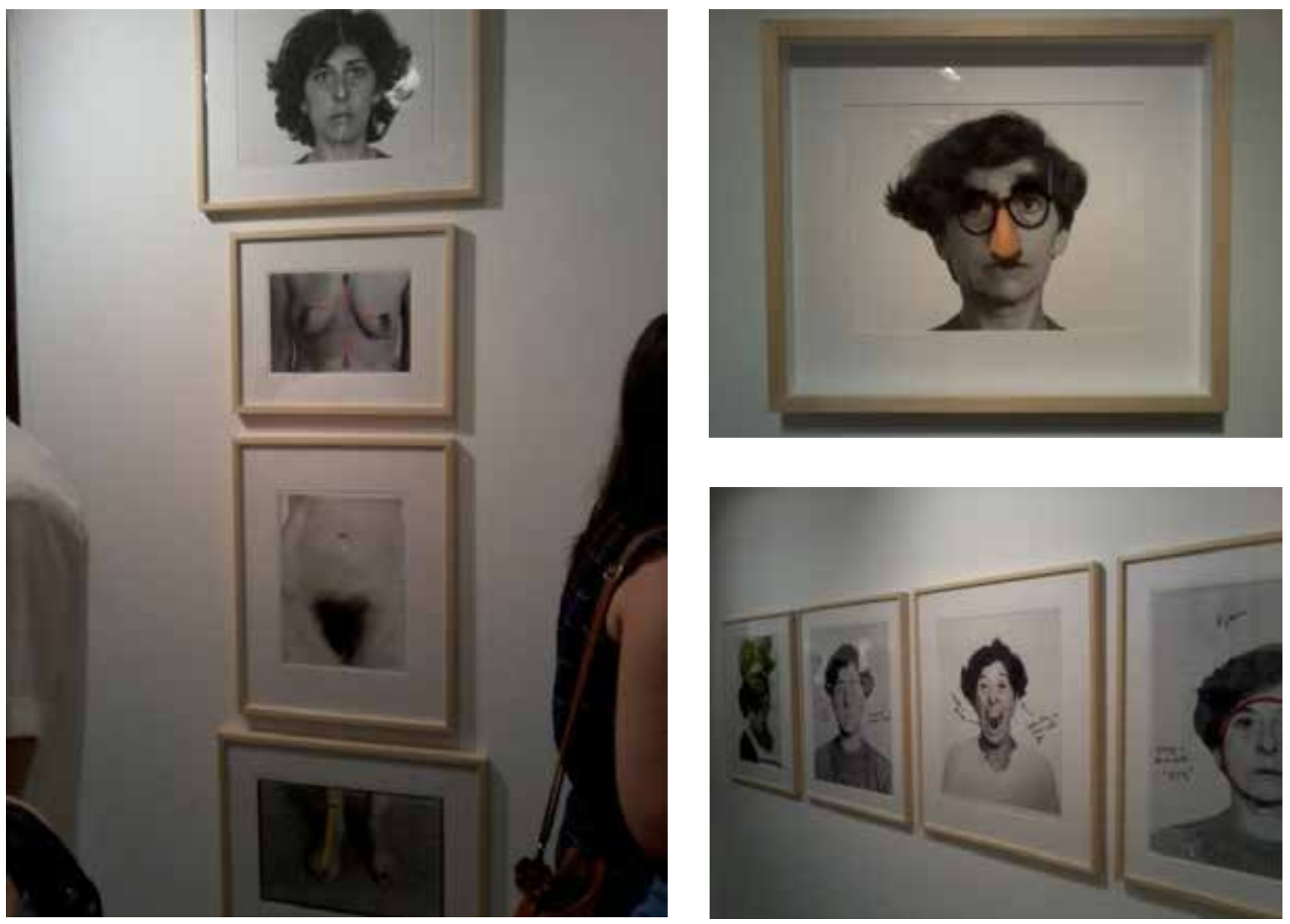

Fig. 9 - ESTHER FERRER, Série Íntimo e Pessoal, 1977-2009.

Fonte: Arquivo da artista

Demonstrando plena conexão entre arte e vida, colocando suas proposições com o corpo em total junção a posicionamentos político-sociais, Esther reflete-se em seu trabalho em uma identidade própria. Mulher-artista, expondo-se e compartiIhando, por meio da arte, o "universo feminino" não glamoroso e cor-de-rosa pintado pela mídia e pela sociedade, se desfazendo em figura, documentos, ações, objetos, não como fim de sua existência, mas como recomeço.

Também, gostaria de aqui comentar proposições de duas jovens artistas que comigo participaram do Festival Performance Brasil, realizado no Rio de Janeiro, em março de 2011. Fernanda Bec e Micheline Torres realizaram performances em que a figura pessoal e íntima da mulher era destruída e/ou alterada como crítica às pressões sobre a imagem feminina construídas na sociedade em que vivemos.

Na performance Autoimagem (Figura 10), a artista Fernanda Bec cuspe e apaga, 
raspando com as próprias unhas, a imagem de seu rosto apresentada em um retrato. Após, com a tinta desta fotografia imbuída em suas mãos, a esfrega em seu próprio rosto, em movimentos delicados como se passasse um creme facial. Por fim, expõe a fotografia apagada em uma moldura de parede e finaliza a performance posicionando-se em pé, com o rosto manchado, ao lado desta.

Da mesma forma em que utilizo meus certificados em $O$ fim $d^{\prime}$ artista, Fernanda recorre a um elemento de representação identitária, no caso, a fotografia de seu rosto, para sobre este e com este, decompor a identidade social que a legitima como indivíduo. A composição facial de uma pessoa é, em geral, uma das principais características de identificação desta, seja pelo Outro que a observa e a detêm na memória, seja por si mesma, na autoafirmação de sua existência. A destruição da face dilui a referência principal da identidade social frente ao Outro, anulando o aspecto fisionômico que mais nos revela e pelo qual melhor nos expressamos.

Fernanda, nesta proposição, desmantela, pela ação violenta que é o arranhar, sua autoimagem, como se, deste modo, pudesse desconstruir tudo aquilo que ao Outro pertence e que a ela faz reconhecer. Ao desconstruir sua face, ela destrói o registro de um passado recente, pintando, com seus resquícios, o presente em pessoa.

A ação de esfregar em seu rosto a tinta que sobrara da fotografia, o modo como essa ação foi realizada, carinhosamente, em movimentos lentos e distribuídos pela face, remetia tanto ao estereótipo feminino da vaidade, midiaticamente construído e incentivado pela indústria cosmética, como também ao do escultor, ceramista, que constrói suas peças alisando sua superfície, modelando no barro, uma nova figura.
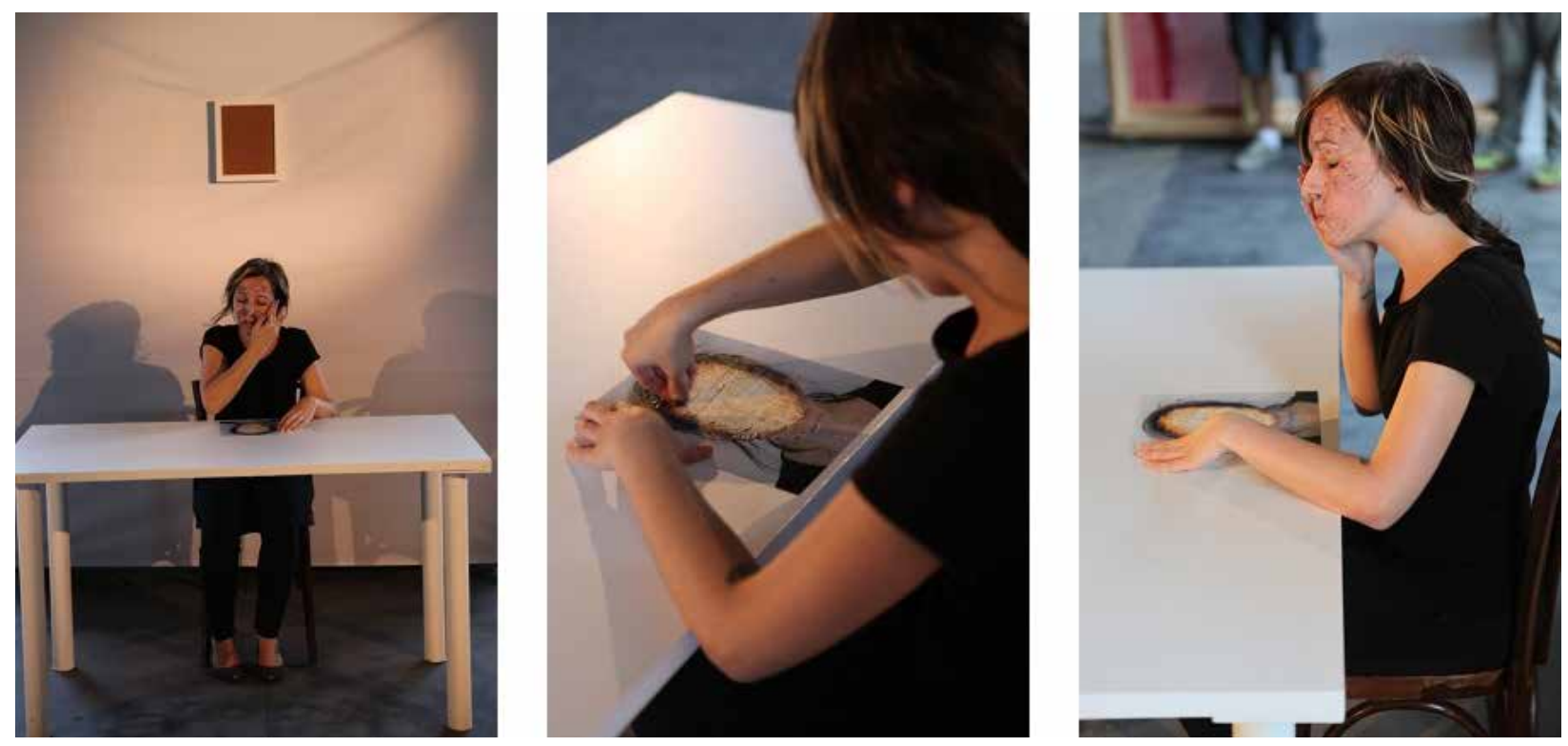

Fig. 10 - FERNANDA BEC, Autoimagem, Rio de Janeiro, 2011.

Fonte: PERFORMANCE BRASIL, 2011.

Micheline Torres realizou, durante o mesmo festival, a performance intitulada Carne (Figura 11). Nesta, em um palco teatral, com número limitado de público, a artista nua esfrega em seu corpo diferentes óleos animais, amarrando-o, posteriormente, com uma borracha hospitalar, de forma firme e violenta. A carne de seu 
corpo, espremida entre as amarras do elástico, acercava a imagem à de alimentos embutidos e queijos que assim são conservados e distribuídos, porém, muito mais que isso, chocava pela violência com que apertava cada parte do corpo, em especial o rosto, alterando-os.

Pensar o corpo humano como pura carne, composta de músculos e gordura, a ser ali trabalhada como matéria flexível, na fragilidade e ao mesmo tempo na resistência do conteúdo, destruía a imagem socialmente alimentada de beleza e singeleza da mulher. O corpo feminino, o próprio corpo, era violentamente abalado por Micheline, desconstruindo sua identidade enquanto pessoa em prol de uma fisicalidade inexpressiva que é a carne.

A desconstrução do rosto, diferente da performance de Fernanda Bec, não era feita pelo apagamento de seus traços em um meio representativo, mas pela alteração brutal de sua composição harmônica de elementos (boca, nariz, olhos, bochechas). Esta perturbação das feições remetia aos procedimentos cirúrgicos, ditos de beleza, estimulados midiaticamente à mulher, que modificam artificialmente sua face, muitas vezes desfigurando-a e retirando desta sua identidade. $O$ rosto desconstruído de Micheline, que figurava um sorriso arrombado pela pressão das borrachas, criticava diretamente a imagem midiatizada da vaidade feminina, segundo a qual o físico, a beleza e a juventude, mesmo que artificial, são futilmente sobrepostas a qualquer identidade e conteúdo.

A trituração dos certificados pessoais, o enterro de ações já não possíveis de serem realizadas, a segmentação das partes do corpo fotografado, o apagamento do rosto em fotografia, a compressão da carne facial, são símbolos da morte, do fenecimento e do fim de uma etapa, de uma identidade, de um ser. A desconstrução de elementos identitários, que provam e atestam a existência, pode ser entendida como um modo de aceitação do devir e também como uma retirada, uma saída, de todo um universo já não possível e/ou desejado.
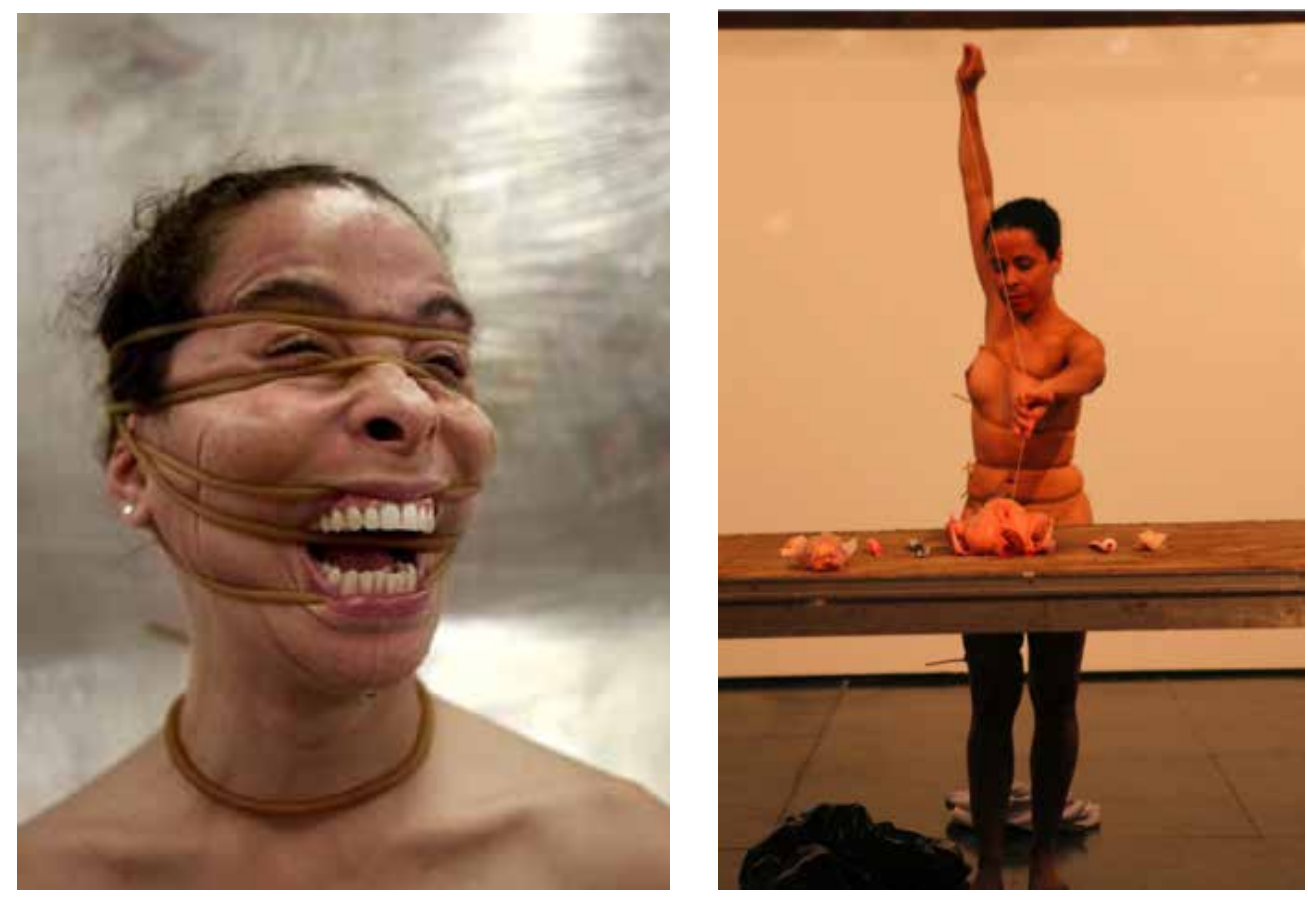

Fig. 11 - MICHELINE TORRES, Carne, Rio de Janeiro, 2011. Fonte: PERFORMANCE BRASIL, 2011. 
Em O fim d' artista, anexado à caixa trituradora, encontra-se um pequeno adesivo escrito: triture aqui seus problemas, levantando a questão do quanto, e quantas vezes, os documentos de nossa existência são, antes de tudo, problemas. O trabalho questiona a posse de certificados e títulos também como uma pressão externa que concorre para a manutenção do status que com eles é obtido.

Existindo uma supremacia do ser social sobre o ser pessoal, exigida e coagida a realizar-se e manter-se, especialmente frente a documentos que a testemunhem, triturar tais papéis é ato crítico incisivo. Apontando-os como problemas, ao longo do vídeo, observa-se que o giro da manivela da máquina trituradora cada vez se apresenta mais rígido e firme. A detenção do papel, como uma negação de triturá-lo, dada pelo acúmulo de resíduos no centro de alimentação da máquina, de certa forma enfatiza a recusa de que se acabe com tudo o que nos certifica e atesta socialmente. Os últimos documentos triturados são duramente recusados pela máquina que, inclusive, chega a romper-se, pela força empregada para que estes sejam "engolidos". Existe, pois, uma determinação em dar fim a tais documentos, exaltando, pela força, o repúdio em mantê-los.

Após toda a primeira parte do vídeo, que traz como áudio o som do papel triturado e a imagem da fragmentação de documentos considerados socialmente importantes para um indivíduo, surge, em silêncio, um último registro: a certidão de nascimento de Helena, apresentando-me em sua filiação como mãe, na prolongação de minha existência na existência de outra pessoa.

Nesta perspectiva, o vídeo O Fim d'Artista mantém-se sempre no mesmo espaço ficcional, mas crível, sem movimentos de câmera, troca de lugares ou de objetos; mantém-se uma constância de captação, que só é alterada durante as ráfagas de zoom nos objetos; a ação de triturar é objetiva e clara, sendo entendida pela sequência repetitiva desta; não há humor, nem sarcasmo, nem zombaria - a ação beira o trágico e o irrevogável, dada a importância que os objetivos centrais, que ali são findados, possuem socialmente; todos os certificados apresentam o mesmo valor, e a ação de triturar mantém-se numa constante até a apresentação de um último papel, que não fora triturado, que é a certidão de nascimento de Helena, exposta em particular ênfase e importância em relação aos demais.

Estas questões pretendem gerar no Outro-espectador assimilação, comoção e identificação pela perda, proposital, dos elementos que nos identificam e nos constroem histórico-socialmente. Posicionando a câmera no lugar do espectador, que olha a ação ocorrendo em seu tempo presente, o que se vê é o olhar do alheio, do Outro. Nisto, se permite que este acompanhe a sensação de determinismo em triturar tais papéis, expressa pela insistência e força com que giro a manivela, mesmo depois que esta se rompe. Andar junto ao meu objetivo de dar fim a todos os papéis, ali apresentados como problemas, é o mote maior frente à recepção do trabalho que, na aparência de verdade, mostra uma identidade perdida e uma nova identidade conquistada. 


\section{Considerações Finais}

No intuito de refletir sobre as possibilidades que o processo criativo possui de levantar, questionar e debater a construção da identidade individual e a presença do Outro, o presente artigo resgatou, da pesquisa doutoral, tal investigação e prática.

Diante da soma de enclausuramento, arraigo e desmantelamento da identidade social, dada pelas contingências envoltas na maternidade, pouco a pouco, e através do processo criativo, pude perceber que havia em mim formas, de sentido pleno e pontual, que me configuravam em unidade diante dos demais. Eram ações, decisões, objetos, pessoas, lugares e tempos que compunham uma nova identidade que deveria, porque não, assumir. A mãe que ali surgira não fazia desaparecer a artista, tampouco a pesquisadora, e menos ainda a mulher, ao contrário, me edificava e me reconstruía.

Com o vídeo O Fim d' artista, a identidade social, representada por certificados, títulos e diplomas, fora expulsa de mim na trituração de tais papéis. Como testemunhas de uma posição e de um status que já não me pertenciam, tais documentos tornaram-se problemas nesta nova etapa em que me inseria, mais do que soluções, como foram em outrora. Era a decomposição do Eu formado por muitas personagens, puzzle de muitos Outros, que agora se triturava em favor de algo novo e não antes experimentado. Por este trabalho, tenta-se instigar o espectador a reconhecer o simulacro de um Eu socialmente criado, mantido por registros e papéis, e que facilmente pode ser eliminado.

Por fim, observo que neste processo criativo um movimento progressivo se deu a favor da construção de um Eu original e confiado. Deliberando e examinando conceitos referentes à identidade e proposições de artistas que nestes se configuram, buscou-se dar a ver como o Eu também pode ser o Outro de outrem. O reflexo desta crise identitária, que desconstrói toda uma formulação sobre alguém que pensamos ser, mas permite também a reconstrução desta percepção, é apresentado pelas narrativas artísticas e, esta exposição autobiográfica é uma forma da arte combater a recorrente e insistente condição atual de aniquilação das subjetividades. O Outro me habita, o Eu o transcende.

\section{Referências}

ABRAMOVIC, Marina. Es mejor dejar tras tu muerte una buena idea que otra basura material. Málaga Hoy, 24 maio, 2014. Entrevista concedida a Pablo Bujalance Málaga. Disponível em: <http://www.granadahoy.com/ocio/dejar-muerte-buena-basura-material_0_810219419.html>. Acessado em: 29 mar. 2018

BEC, Fernanda. Autoimagem. In: PERFORMANCE ARTE BRASIL, Rio de Janeiro, 2011. Imagens. Disponível em: <http://www.performanceartebrasil.com.br/imagens/>. Acesso em:15 mai. 2016

BECKER, Jéssica. Trama de nós-cegos: Contextos, Contatos e Conexões no Centro de Porto Alegre. TCC (Bacharelado em Artes Visuais/Escultura). Instituto de Artes da UFRGS, 2006c. 
O Estranhamento na Arte Contemporânea: Uma Abordagem sobre as obras de Elaine Tedesco e Élida Tessler. TCC (História, Teoria e Crítica). Instituto de Artes da UFRGS, 2008.

Arte de acción y su (re)presentación a través del vídeo em espacios legitimados del arte. Dissertação (Máster em Produção Artística). Universidad Politécnica de Valencia/Espanha, 2010b.

Cotidiano experimentado: o processo criativo na prática de ações. Dissertação (Mestrado em Poéticas Visuais). PPGAV-IA/UFRGS, 2011b.

BENJAMIN, Walter. O Narrador. In: Obras escolhidas: Mágia e Técnica, Arte e Política. São Paulo: Editora Brasiliense, 1996.

BERNARDAC, Marie-Laure; BOURGEOIS, Louise; OBRIST, Hans-Ulrich. Louise Bourgeois: destruição do pai, reconstrução do pai. São Paulo, Cosac Naify, 2000.

FERRER, Esther. Esther Ferrer: Maquetas y dibujos de instalaciones 1970/2011. Madri: Exit Publicaciones, 2011.

La performance es un arte impuro. In: Jornal El País. Espanha, 27 fev 2014. Disponível em: <http://ccaa.elpais.com/ccaa/2014/02/27/paisvasco/1393522258_719339.html>. Acessado em: 06 ago. 2014.

GENETTE, Gérard. Discurso del relato. In: Figuras III. Barcelona: Lumen,1989.

HONNETH, Axel. O eu no nós: reconhecimento como força motriz de grupos. Porto Alegre: Revista Sociologias, ano 15, n. 33, maio/ago, 2013, p. 56-80. Disponível em:<www.scielo.br/pdf/soc/v15n33/v15n33a03.pdf>. Acesso em03 fev. 2016.

KRAUSS, Rosalind. Video: The Aesthetics of Narcissism.1976. Disponível em: <https://people.ucsc.edu/ ilusztig/176/downloads/reading/rosalindkraus.pdf>. Acesso em:12 set. 2015.

LOUISE Bourgeois: o retorno do desejo proibido. Catálogo. São Paulo: Instituto Tomie Ohtake, 2011.

Tejiendo el tiempo. Catálogo. Málaga: CAC, 2004. Disponível em: <http://cacmalaga.eu/2004/08/06/louise-bourgeois-2/>. Acesso em: 22 jan. 2016

MATALLÍA, Lorena Rodrigues. Arte videográfico: inicios, polémicas y parámetros básicos de análisis.Valência: Editorial de la UPV, 2008. 
MAYERS, Monica; BUSTAMANTE, Maris. Madre por um día. Ciudad de México: 1987. Nuestro Mundo. Entrevista concedida a Guillermo Ochoa. Disponível em: $<$ https://www.youtube.com/watch?v=abaDXr3HKck>. Acesso em: 29 mar. 2018

AVJ Ediciones, 2004.

Rosa Chillante: mujeres y performance en México. México:

PERFORMANCE Brasil Festival. Publicação da exposição. LABRA, Daniela(org.). Catálogo. Rio de Janeiro: MAM, 2011.

ROSSET, Clément. Lejos de mí: Estudio sobre la identidad. Barcelona: Marbot Ediciones, 2007.

Lo Invisible. Madri: El cuenco de Plata, 2014.

L’Objet Singulier. Paris: Les Éditions de Minute, 1995.

TORRES, Micheline. Carne. In: PERFORMANCE ARTE BRASIL, Rio de Janeiro, 2011. Imagens. Disponível em: <http://www.performanceartebrasil.com.br/imagens/>. Acesso em: 15 nov. 2015 